\title{
XXXI. Note on the subject of a paper by Prof. L. T. More : "On the supposed elongation of a dielectric in an electrostatic field"
}

\section{Dr. P. Sacerdote}

To cite this article: Dr. P. Sacerdote (1901) XXXI. Note on the subject of a paper by Prof. L. T. More : "On the supposed elongation of a dielectric in an electrostatic field" , Philosophical Magazine Series 6, 1:3, 357-359, DOI: 10.1080/14786440109462620

To link to this article: http://dx.doi.org/10.1080/14786440109462620

曲 Published online: 16 Apr 2009.

Submit your article to this journal $₫$

Џll Article views: 2

Q View related articles $\longleftarrow$

Citing articles: 1 View citing articles 5 
XXXI. Note on the subject of a Paper by Prof. L. 'T. More: "On the supposed Elongation of a Dielectric in an Electrostatic Field"*. By Dr. P. Sacerdote $†$.

DROF. L. T. MORE, of the University of Nebraska, has recently published an account of a series of experiments. in which he purposed measuring the elongation experienced by a glass tube forming the dielectric of a cylindrical condenser when the condenser is charged. In none of his experiments did he succeed in observing any elongation or contraction of the tube: from this he concludes that no electrical deformations of dielectrics exist, and that those observed by Govi, Duter, Righi, Quincke, \&c. were only dne to disturbing causes. In the present note $I$ shall show that the conclusion to be drawn from Prof. More's paper is quite different. By the very disposition of his experiments the tube should not experience any appreciable elongation; thus the negative result of his experiments merely proves that they were carefully performed.

1. For the description of the apparatus I refer to Prof. More's paper, merely recalling that it consisted essentially of a glass tube A, $2.5 \mathrm{~mm}$. thick, and of two coaxial metal tubes $\mathrm{B}^{\prime} \mathrm{B}^{\prime \prime}$, which constitute the armatures, the one $\mathrm{B}^{\prime}$ interior, the other $\mathrm{B}^{\prime \prime}$ exterior to $\mathrm{A}$, from which they are separated by an interval; the arrangement for magnifying the dilatation was such that one division of the micrometer eyepiece corresponded to an elongation of $A$ of $\frac{1 \cdot 5}{100}$ micron $\ddagger$.

First Experiment.-The space between $B^{\prime}$ and $A$, as well as that between $\mathrm{A}$ and $\mathrm{B}^{\prime \prime}$, is filled with an insulating liquid; then, the armature $B^{\prime}$ being earthed, $B^{\prime \prime}$ is charged by an electric machine. In no case did Prof. More obtain any displacement of the reflected image by the amplifying mirror.

Second Experiment.-The cylinder $\mathrm{B}^{\prime \prime}$ is removed and replaced by tinfoil $45 \mathrm{~cm}$. long cemented on $A$. The space between $\mathrm{B}^{\prime}$ and $\mathrm{A}$ is filled with acidulated water forming the internal armature. Prof. More still obtained no elongation or contraction, even on charging this condenser to high potentials corresponding to sparks of $12 \mathrm{~mm}$. to $20 \mathrm{~mm}$. between two brass knobs of $2 \mathrm{~cm}$. diameter.

* Phil. Mag. vol. I. pp. 198-210 (1900).

+ Communicated by the Author.

I I omit all criticisu relative to the apparatus, although in my ofinion, for such small displacements, direct measurement by interference-fringes is the only one that can be relied on, and it is in any case much prefer-able to any mechanical process of amplification. 
2. Discussion of the Second Experiment.-In this experiment we have to do with a condenser of which the dielectric is the glass and the armatures are adherent to the dielectric and follow its deformations ; these conditions are quite analogous to those in the experiments of Righi, Quincke, and Cantone*. On the basis of the figures obtained by this last author, we can calculate a priori the elongation which the tube should undergo in the experiments of Prof. More. Let

$l$ be the length of the condenser,

$\Delta l$ be its elongation when charged to the potential $\mathrm{V}$, $e$ be the distance between the armatures, which is here equal to the thickness of the dielectric.

Cantone's experiments give for the expression $\left(\frac{\Delta l}{l} \times \frac{e^{2}}{\mathrm{~V}^{2}}\right) \dagger$ values $\ddagger$ varying between 4.6 and $7 \cdot 1 \times 10^{-13}$ : let us take the mean, $6 \times 10^{-13}$. Denoting by $x$ the elongation to be predicted for the tube in Prof. More's experiment (for a sparkJength of $12 \mathrm{~mm} ., \mathrm{V}=110$ c.G.s.), we have

$$
\frac{x}{45} \times \frac{(0 \cdot 25)^{2}}{(110)^{2}}=6 \times 10^{-13} \text {, }
$$

* In a long criticism of the experimental work on this question (Sacerdote, " Recherches théoriques sur les déformations électriques des diélectriques solides isotropes," Annales de phys, et chimie, sér. 7, t. xx. pp. 289-377; abstract, Journ. de Phys. sér. 3, t. viii. Sept.-Oct. 1899) f have already shown (pp. 344-369) that the experiments of Duter, Righi, and Quincke should only be considered from the qualitative point of view; while those of Prof. Cantone (Rendiconti della $R$. Acc. dei Lincei, ser. 4, t. iv. pp. 344-353, 471-477, 1888), in which the elongation is measured directly by the displacement of interference-fringes, present far greater guarantees of accuracy, and that these are the only ones the numerical results of which can be depended on. Prof. More does not appear to have been acquainted either with my paper or with the experiments of Prof. Cantone.

$\downarrow$ The formula for the electric deformation of a thin cylindrical condenser with adherent armatures is

$$
\frac{\Delta l}{l}=\left(a+k_{1}\right) \frac{\mathrm{KV}^{2}}{8 \pi e^{2}}
$$

in which $a, k_{1}, \mathrm{~K}$ are coefficients depending solely on the nature of the dielectric (for the proof of this formula and the meaning of the coefficients see Sacerdote, loc, cit. p. 307); the quantity $\frac{\Delta l}{l} \times \frac{e^{2}}{\mathrm{~V}^{2}}$ should thus be sensibly the same in the experiments of Prof. More and in those of Prof. Cantone.

$\ddagger$ See Sacerdote, loc. cit. table on p. 368; these numbers have just been confirmed by recent researches (Cantone \& Sozzani, "Nuovo Ricerche intorno alla Deformazione dei Condensatori," Rendiconti della $R$. Istituto Lombardo, ser. 2, t. xxxiii. 1900). 
whence

$$
x=\frac{5 \cdot 2}{100} \text { micron *, }
$$

which corresponds to only $3 \frac{1}{2}$ divisions of the micrometer eyepiece $†-$ a displacement which evidently could not be observed with certainty, since on pp. 202, 203 of his paper Prof. More mentions displacements of the zero of the micrometer which exceed 3 divisions $\ddagger$.

Discussion of the First Experiment.-In the second experiment we had to deal with a thin condenser with adherent armatures; the dilatation being in this case given by the formula $\S$

$$
\frac{\Delta l}{l}=\left(a+k_{1}\right) \frac{K H^{2}}{8 \pi}, . . . . . .
$$

$\mathrm{H}$ denoting the intensity of the electric field in the glass $(\mathrm{H}=\mathrm{V} / \mathrm{e})$. In the first experiment we have, on the contrary, a condenser with armatures independent of the glass tube, since they are separated from it by a liquid dielectric; the dilatation is thus given by the formula \||

$$
\frac{\delta l}{l}=k_{1} \frac{\mathrm{K} h^{2}}{8 \pi}, . . . . . .
$$

$h$ denoting the new intensity of the electric field in the glass. But as :

(1) The coefficient $k_{1}$ is considerably smaller than $\left(a+k_{1}\right)$ I:

(2) The field $h$ is much less intense than $\mathrm{H}$, since the potential-differences were the same and the distance between the armatures much greater.

The elongation $\delta l$ will thus be much smaller still than $\Delta l$, and consequently absolutely inappreciable.

* For a spark-length of $20 \mathrm{~mm} .(\mathrm{V}=130 \mathrm{c.G.S}) \quad x=\frac{7 \cdot 3}{100}$ micron-that is to say, less than 5 divisions of the micrometer.

+ Prof. Cantone used tubes having a length of 60 to $70 \mathrm{~cm}$. and $a$ thickness of only $0 \cdot 4$ to $0 \cdot 6 \mathrm{~mm}$; ; and we know that the dilatation increases in proportion to the length and in inverse ratio to the square of the thickness.

$\ddagger$ Prof. More, who had also the trouble to make this preliminary calculation, hoped to obtain elongations of 20 to 30 divisions; but, as he was not aware of the work of Prof. Cantone, he based this expectation on the experiments of Righi and Quincke, which, I repeat (see note (*), p. 358), are altogether to be rejected from a quantitative standpoint.

\$ See note $(\uparrow)$, p. 358 .

II For the proof of this formula, see Sacardote, Jour. de Phys. Feb.Mar. 1901.

I) (See Sacerdote, loc. cit. p. 372.) $k_{1}$ is of the order 10-12 c.G.s. and $a$ nearly equal to $1.6 \times 10-12$ c.G.s. 